\title{
Influence of Four Radiotracers in PET/ CT on Diagnostic Accuracy for Prostate Cancer: A Bivariate Random-Effects Meta-Analysis
}

\author{
Junzhong Liu ${ }^{\mathrm{a}}$ Zhongfeng Chen ${ }^{\mathrm{b}}$ Tianyu Wang ${ }^{\mathrm{c}}$ Li Liu $^{\mathrm{a}}$ Lei Zhao \\ Guangtao Guo a Dongqing Wang ${ }^{c}$
}

\begin{abstract}
aDepartment of Interventional, Zhengzhou Central Hospital Affiliated to Zhengzhou University, Zhengzhou, 'Department of Nephrology, Zhengzhou Central Hospital Affiliated to Zhengzhou University, Zhengzhou, 'Department of Radiology, Zhengzhou Central Hospital Affiliated to Zhengzhou University, Zhengzhou, China
\end{abstract}

\section{Key Words}

$\mathrm{PET} / \mathrm{CT} \cdot$ Diagnosis $・$ Prostate cancer $・$ Meta-analysis

\begin{abstract}
Background/Aims: To date, several positron emission tomography/computed tomography (PET/CT) radiotracers including fluorine-18 fluorodeoxyglucose (18F-FDG), carbon-11 labeled choline (11C-choline), 18-F fluorocholine (18F-FCH) and carbon-11 acetate (11C-acetate) have already been assessed in the application of prostate cancer ( $\mathrm{PCa}$ ) diagnosis to some extent, the diagnostic efficiency of these radiotracers still remain controversial. As a result of this, we carried out this meta-analysis for the purpose of comparing the diagnostic accuracy among four PET/CT radiotracers. Methods: A systematical literature search for articles was performed until July 3,2015. We implemented all analysis using the statistical software of STATA12 and quality assessment was performed using QUADAS-2. Results: A total of 56 studies containing 3,586 patients were included in this meta-analysis. Parameter estimates of the overall analysis are as follows: sensitivity, 0.80 (95\% CI: 0.74-0.85); specificity, 0.84 (95\% CI: 0.77-0.89) and area under roc curve-AUC of SROC, 0.89 (95\% CI: 0.86-0.91), indicating a relatively high level of accuracy in diagnosis of $\mathrm{PCa}$. When different radiotracers of PET/CT were compared, 18F-FCH-PET/CT was ranked as the most favorable with the highest value of AUC (AUC $=0.94 ; 95 \%$ CI: 0.92-0.96) whereas 18F-FDG was the least favorable (AUC $=0.73$, $95 \%$ CI: 0.69-0.77). Conclusion: This study suggested that PET/CT imaging plays an invaluable role in the diagnosis of PCa and 18F-FCH-PET/CT was considered as a superior diagnostic tool over other radiotracers. More attention should be paid to the diagnostic efficiency of the four radiotracers particularly for PCa patients with different clinical stages.
\end{abstract}

J. Liu and Z. Chen contributed equally to this work and are the co-first authors.

Dongqing Wang Department of Radiology, Zhengzhou Central Hospital Affiliated to Zhengzhou

University, No. 195 Tongbai Road, Zhengzhou, Henan, 450000, (China)

Tel. / Fax +86-0371-67690507, E-Mail dryujie_wang@yeah.net 


\section{Introduction}

Prostate cancer (PCa) is the most prevalent solid malignancy occurred in males over the world with an incidence rate of 70 cases per 100,000 males [1]. PCa has been considered as a severe health issue in developed countries compared with that in developing countries. The number of PCa cases in developed countries is approximately twice as high as that in developing countries as aging males are susceptible to the development of PCa [2, 3]. Early and accurate diagnosis of PCa is critical to the selection of optimal treatment and the prognosis of PCa patients. For example, radical prostatectomy is suitable for patients with organ-confined PCa whereas life extending therapy or systemic therapeutic regimen is appropriate for patients with impregnated or diffused PCa.

Primary imaging techniques such as bone scintigraphy and ultrasound have their own limitations, PET/CT has been sought to improve the staging of PCa [4-6]. The integrated imaging modality of PET/CT has substantial advantages in cancer localization and staging due to its combination of anatomic and metabolic information [7]. Several PET/CT radiotracers have been developed in the diagnosis of $\mathrm{PCa}$, including fluorine-18 fluorodeoxyglucose (18F-FDG), carbon-11 labeled choline (11C-choline), 18-F fluorocholine (18F-FCH) and carbon-11 acetate (11C-acetate).

Although 18F-FDG, which is commonly used for diagnosing various kinds of tumor, has a suitable half-life (110 $\mathrm{min})$ and presents excellent performance on tracking glucose metabolism in malignant lesions, it has very limited capacity in PCa work-up because PCa generally displays low glucose metabolism due to slow cancer growth [8-10]. Furthermore, urinary excretion of 18F-FDG could interrupt the molecular imaging and FDG accumulation may also occur in benign prostatic hypertrophy or inflammation, resulting in a low sensitivity in the detection of PCa [11-13].

Analogous imaging results are found in 11C-choline and 18F-FCH due to the same rationale for choline which is a vital portion of phosphatidylcholine that comprises the cell membrane. A rise in choline is attributable to an increase in cell proliferation and up-regulated choline-kinase activity [14-16]. Nevertheless, several distinctions between the two probes have been reported. For instance, 11C-choline provides clear images for pelvic regions for its feature of low urinary excretion and is considered to be limited for centers without on-site cyclotron because of its short half-life (20 min). By contrast, 18F-FCH possesses a longer half-life (110 min) which makes off-site transportation feasible, but it is subject to higher urinary activity $[14,17,18]$.

As suggested by other studies, 11C-acetate was transformed into acetyl-CoA and then converted into fatty acid which has strength in visualizing the over-expressed fatty acid synthesis in PCa cells [19-21]. Moreover, the predominant elimination pathway of $11 \mathrm{C}$-acetate is oxidized into carbon dioxide which explains the minimal bladder activity [19, 22, 23].

Comparison of imaging techniques among 18F-FDG PET/CT, 11C-choline PET/CT, 18F-FCH PET/CT and 11C-acetate PET/CT for PCa diagnosis has not been formerly reported. Therefore, this meta-analysis was designed for this specific purpose.

\section{Materials and Methods}

Search Strategy

A systematical literature search for relevant articles was performed in PubMed, Cochrane Library, Google Scholar, Medline and Embase with the key terms "prostate cancer, diagnosis, positron emission tomography/computed tomography" (updated to July 3, 2015).

Inclusion criteria and data extraction

In this meta-analysis, studies were included if matching the following criteria: studies focus on investigating the diagnostic performance of four PET/CT radiotracers in PCa; the values of true/false- 


\begin{tabular}{|c|c|c|}
\hline Cellular Physiology & $\begin{array}{l}\text { Cell Physiol Biochem 2016; } \\
\text { DOI: 10.159/000445639 }\end{array}$ & 9:467-480 \\
\hline and Biochemistry & $\begin{array}{l}\text { DOI: 10.1159/000445639 } \\
\text { Published online: July 07, } 2016\end{array}$ & $\begin{array}{l}\text { O } 2016 \text { The Author(s). Published by S. Karger AG, Basel } \\
\text { www.karger.com/cpb }\end{array}$ \\
\hline
\end{tabular}

Liu et al.: PET/CT for PCa diagnosis

positive, true/false-negative can be calculated.

Two authors perused the full text of eligible studies and extracted the following relevant information: basic study information (first author, year of publication, publishing country), type of PET/CT and data needing for meta-analysis. When the data of sensitivity and specificity were not reported in the text, we estimated these figures by corresponding SROC curves. Missing data contained in eligible studies was sought from authors via e-mail request.

\section{Quality assessment}

Quality assessment was independently performed by two reviewers using QUADAS-2 which concerns about four key domains (patient selection, index test, reference standard and flow timing). [24]. The quality of the studies was evaluated by examining 10 questions and each question should be answered with "yes", "no", or "unclear". An answer of "yes" gets one score, which means low risk of bias, whereas an answer of "no" or "unclear" gains a score of "0" which suggests that a high risk of bias may exist (Table 1).

Table 1. Main characteristics of included studies in the systematic meta-analyses

\begin{tabular}{|c|c|c|c|c|c|c|c|c|c|c|c|}
\hline First author & Year & Country & Ethnicity & Type of PET/CT & $\mathrm{TP}$ & FP & $\mathrm{FN}$ & $\mathrm{TN}$ & Sensitivity $(95 \% \mathrm{Cl})$ & Specificity $(95 \% \mathrm{Cl})$ & QUADAS 2 \\
\hline Wachter & 2006 & Austria & Caucasian & $11 \mathrm{C}$-acetate & 12 & 1 & 1 & 3 & $0.92(0.64-1.00)$ & $0.75(0.19-0.99)$ & $8 / 10$ \\
\hline Jambor & 2010 & Finland & Caucasian & $11 \mathrm{C}$-acetate & 28 & 5 & 7 & 2 & $0.80(0.23-0.92)$ & $0.29(0.04-0.71)$ & $7 / 10$ \\
\hline Mena & 2012 & America & Caucasian & $11 \mathrm{C}$-acetate & 47 & 37 & 17 & 66 & $0.73(0.61-0.84)$ & $0.64(0.54-0.73)$ & $9 / 10$ \\
\hline Jambor & 2012 & Finland & Caucasian & $11 \mathrm{C}$-acetate & 44 & 13 & 6 & 9 & $0.88(0.76-0.95)$ & $0.41(0.21-0.64)$ & $7 / 10$ \\
\hline Haseebuddin & 2013 & America & Caucasian & $11 \mathrm{C}$-acetate & 17 & 18 & 8 & 64 & $0.68(0.46-0.85)$ & $0.78(0.68-0.86)$ & $7 / 10$ \\
\hline Kotzerke & 2000 & Germany & Caucasian & 11C-choline & 1 & 1 & 1 & 9 & $0.50(0.01-0.99)$ & $0.90(0.55-1.0)$ & $7 / 10$ \\
\hline Farsad & 2005 & Italy & Caucasian & 11C-choline & 35 & 3 & 1 & 2 & $0.97(0.85-1.0)$ & $0.40(0.05-0.85)$ & $7 / 10$ \\
\hline Reske & 2006 & Germany & Caucasian & 11C-choline & 363 & 61 & 86 & 426 & $0.81(0.77-0.84)$ & $0.87(0.84-0.90)$ & $7 / 10$ \\
\hline Martorana & 2006 & Italy & Caucasian & 11C-choline & 107 & 15 & 56 & 80 & $0.66(0.58-0.73)$ & $0.84(0.77-0.91)$ & $8 / 10$ \\
\hline Testa & 2007 & Italy & Caucasian & 11C-choline & 53 & 8 & 45 & 50 & $0.54(0.44-0.64)$ & $0.86(0.75-0.94)$ & $6 / 10$ \\
\hline Scher & 2007 & Germany & Caucasian & 11C-choline & 32 & 8 & 5 & 13 & $0.86(0.71-0.95)$ & $0.62(0.38-0.82)$ & $7 / 10$ \\
\hline Scattoni & 2007 & Italy & Caucasian & 11C-choline & 19 & 2 & 0 & 4 & $1.00(0.82-1.00)$ & $0.67(0.22-0.96)$ & $7 / 10$ \\
\hline Igerc & 2007 & Austria & Caucasian & 11C-choline & 5 & 8 & 0 & 7 & $1.00(0.48-1.00)$ & $0.47(0.21-0.73)$ & $8 / 10$ \\
\hline Rinnab & 2007 & Germany & Caucasian & 11C-choline & 38 & 6 & 2 & 4 & $0.95(0.83-0.99)$ & $0.40(0.12-0.74)$ & $8 / 10$ \\
\hline Schiavina & 2008 & Italy & Caucasian & 11C-choline & 9 & 1 & 6 & 41 & $0.60(0.32-0.84)$ & $0.98(0.87-1.00)$ & $8 / 10$ \\
\hline Reske & 2008 & Germany & Caucasian & 11C-choline & 23 & 4 & 10 & 12 & $0.70(0.51-0.84)$ & $0.75(0.48-0.93)$ & $7 / 10$ \\
\hline $\mathrm{Li}$ & 2008 & China & Asian & 11C-choline & 19 & 4 & 2 & 24 & $0.90(0.70-0.99)$ & $0.86(0.67-0.96)$ & $6 / 10$ \\
\hline Giovacchini & 2008 & Italy & Caucasian & 11C-choline & 48 & 27 & 19 & 20 & $0.72(0.59-0.82)$ & $0.43(0.28-0.58)$ & $6 / 10$ \\
\hline Rinnab & 2009 & Germany & Caucasian & 11C-choline & 29 & 7 & 2 & 3 & $0.94(0.79-0.99)$ & $0.30(0.07-0.65)$ & $8 / 10$ \\
\hline Winter & 2009 & Germany & Caucasian & 11C-choline & 9 & 2 & 0 & 12 & $1.00(0.66-1.00)$ & $0.86(0.57-0.98)$ & $7 / 10$ \\
\hline Breeuwsma & 2010 & Germany & Caucasian & 11C-choline & 57 & 0 & 13 & 10 & $0.81(0.70-0.90)$ & $1.00(0.69-1.00)$ & $8 / 10$ \\
\hline Giovacchini & 2010 & Italy & Caucasian & 11C-choline & 65 & 10 & 10 & 85 & $0.87(0.77-0.93)$ & $0.89(0.81-0.95)$ & $6 / 10$ \\
\hline Winter & 2010 & Germany & Caucasian & 11C-choline & 6 & 0 & 0 & 10 & $1.00(0.54-1.00)$ & $1.00(0.69-1.00)$ & $6 / 10$ \\
\hline Giovacchini & 2010 & Italy & Caucasian & 11C-choline & 145 & 14 & 26 & 173 & $0.85(0.79-0.90)$ & $0.93[0.88-0.96)$ & $6 / 10$ \\
\hline Fuccio & 2010 & Italy & Caucasian & 11C-choline & 19 & 0 & 3 & 3 & $0.86(0.65-0.79)$ & $1.00(0.29-1.00)$ & $8 / 10$ \\
\hline Watanable & 2010 & Japan & Asian & 11C-choline & 19 & 7 & 7 & 10 & $0.73(0.52-0.88)$ & $0.59(0.33-0.82)$ & $7 / 10$ \\
\hline Contractor & 2011 & UK & Caucasian & 11C-choline & 7 & 3 & 2 & 14 & $0.78(0.40-0.97)$ & $0.82(0.57-0.96)$ & $9 / 10$ \\
\hline Bertagna & 2011 & Italy & Caucasian & 11C-choline & 6 & 3 & 4 & 32 & $0.60(0.26-0.88)$ & $0.91(0.77-0.98)$ & $7 / 10$ \\
\hline Budiharto & 2011 & Belgium & Caucasian & 11C-choline & 3 & 1 & 13 & 19 & $0.19(0.04-0.46)$ & $0.95(0.75-1.00)$ & $6 / 10$ \\
\hline Bergh & 2011 & Germany & Caucasian & 11C-choline & 363 & 390 & 106 & 317 & $0.77(0.73-0.81)$ & $0.45(0.41-0.49)$ & $7 / 10$ \\
\hline Picchio & 2012 & Italy & Caucasian & 11C-choline & 24 & 0 & 3 & 51 & $0.89(0.71-0.98)$ & $1.00(0.93-1.00)$ & $7 / 10$ \\
\hline Glovacchini & 2012 & Switzerland & Caucasian & 11C-choline & 63 & 3 & 7 & 2 & $0.91(0.82-0.96)$ & $0.40(0.05-0.85)$ & $8 / 10$ \\
\hline Mitchell & 2013 & America & Caucasian & 11C-choline & 106 & 11 & 8 & 35 & $0.93(0.87-0.97)$ & $0.76(0.61-0.87)$ & $6 / 10$ \\
\hline Jilg & 2014 & America & Caucasian & 11C-choline & 102 & 26 & 9 & 23 & $0.92(0.85-0.96)$ & $0.47(0.33-0.62)$ & $7 / 10$ \\
\hline Heck & 2014 & Germany & Caucasian & 11C-choline & 8 & 3 & 6 & 30 & $0.57(0.29-0.82)$ & $0.91(0.76-0.98)$ & $9 / 10$ \\
\hline Kitajima & 2014 & America & Caucasian & 11C-choline & 118 & 3 & 37 & 120 & $0.76(0.69-0.83)$ & $0.97(0.97-0.99)$ & $7 / 10$ \\
\hline Minamimoto & 2010 & Japan & Asian & 18 F-FDG & 27 & 36 & 25 & 112 & $0.52(0.38-0.66)$ & $0.76(0.68-0.82)$ & $8 / 10$ \\
\hline Hwang & 2012 & Korea & Asian & 18 F-FDG & 20 & 65 & 3 & 32 & $0.87(0.66-0.97)$ & $0.33(0.24-0.43)$ & $7 / 10$ \\
\hline Shiiba & 2012 & Japan & Asian & 18 F-FDG & 58 & 18 & 36 & 72 & $0.62(0.51-0.72)$ & $0.80(0.70-0.88)$ & $7 / 10$ \\
\hline Damle & 2013 & India & Asian & 18F-FDG & 23 & 0 & 9 & 17 & $0.72(0.53-0.86)$ & $1.00(0.80-1.00)$ & $7 / 10$ \\
\hline Yang & 2014 & China & Asian & $18 \mathrm{~F}-\mathrm{FDG}$ & 13 & 25 & 7 & 55 & $0.65(0.41-0.85)$ & $0.69(0.57-0.79)$ & $8 / 10$ \\
\hline Kwee & 2005 & America & Caucasian & 18F-FCH & 64 & 17 & 5 & 16 & $0.93(0.84-0.98)$ & $0.48(0.31-0.66)$ & $7 / 10$ \\
\hline Hacker & 2006 & Austria & Caucasian & $18 \mathrm{~F}-\mathrm{FCH}$ & 1 & 2 & 9 & 8 & $0.10(0.00-0.45)$ & $0.80(0.44-0.97)$ & $8 / 10$ \\
\hline Husarik & 2007 & Switzerland & Caucasian & $18 \mathrm{~F}-\mathrm{FCH}$ & 1 & 0 & 2 & 22 & $0.33(0.01-0.91)$ & $1.00(0.85-1.00)$ & $9 / 10$ \\
\hline Pelosi & 2007 & Italy & Caucasian & $18 \mathrm{~F}-\mathrm{FCH}$ & 24 & 1 & 0 & 26 & $1.00(0.86-1.00)$ & $0.96(0.81-1.00)$ & $6 / 10$ \\
\hline Vees & 2007 & Switzerland & Caucasian & $18 \mathrm{~F}-\mathrm{FCH}$ & 3 & 2 & 5 & 1 & $0.38(0.09-0.76)$ & $0.33(0.01-0.91)$ & $8 / 10$ \\
\hline Pelosi & 2008 & Italy & Caucasian & $18 \mathrm{~F}-\mathrm{FCH}$ & 24 & 1 & 5 & 26 & $0.83(0.64-0.94)$ & $0.96(0.81-1.00)$ & $7 / 10$ \\
\hline Behesht1 & 2010 & Austria & Caucasian & $18 \mathrm{~F}-\mathrm{FCH}$ & 18 & 4 & 22 & 86 & $0.45(0.29-0.62)$ & $0.96(0.89-0.99)$ & $7 / 10$ \\
\hline Steuber & 2010 & Germany & Caucasian & $18 \mathrm{~F}-\mathrm{FCH}$ & 0 & 0 & 31 & 254 & $0.00(0.00-0.01)$ & $1.00(0.99-1.00)$ & $7 / 10$ \\
\hline Beheshti & 2010 & Austria & Caucasian & $18 \mathrm{~F}-\mathrm{FCH}$ & 207 & 3 & 56 & 96 & $0.79(0.73-0.83)$ & $0.97(0.91-0.99)$ & $8 / 10$ \\
\hline Poulsen & 2010 & Denmark & Caucasian & $18 \mathrm{~F}-\mathrm{FCH}$ & 3 & 1 & 0 & 21 & $1.00(0.29-1.00)$ & $0.95(0.77-1.00)$ & $7 / 10$ \\
\hline Langsteger & 2011 & Austria & Caucasian & $18 \mathrm{~F}-\mathrm{FCH}$ & 20 & 2 & 2 & 16 & $0.91(0.71-0.99)$ & $0.89(0.65-0.99)$ & $8 / 10$ \\
\hline McCarthy & 2011 & Austria & Caucasian & $18 \mathrm{~F}-\mathrm{FCH}$ & 150 & 1 & 6 & 26 & $0.96(0.92-0.99)$ & $0.96(0.81-1.00)$ & $6 / 10$ \\
\hline Oprea-Lager & 2012 & Sweden & Caucasian & 18F-FCH & 35 & 1 & 2 & 16 & $0.95(0.82-0.99)$ & $0.94(0.71-1.00)$ & $6 / 10$ \\
\hline Panebianco & 2012 & Italy & Caucasian & $18 \mathrm{~F}-\mathrm{FCH}$ & 48 & 2 & 4 & 1 & $0.92(0.81-0.98)$ & $0.33(0.01-0.91)$ & $7 / 10$ \\
\hline Poulsen & 2012 & Denmark & Caucasian & $18 \mathrm{~F}-\mathrm{FCH}$ & 30 & 21 & 11 & 148 & $0.73(0.57-0.86)$ & $0.88(0.82-0.92)$ & $9 / 10$ \\
\hline
\end{tabular}

TP: true-positive; FP: false-positive; TN: true-negative; FP. false negative; CI: conffidence interval: SEN: sensitivity; SPE: specifciry: PET/CT: positron emission tomography/computed tomography; FCH: 
Statistical methods

Statistical heterogeneity was evaluated by the statistic of $Q$ and $I^{2}$. $P<0.01$ and $I^{2}>50 \%$ indicates significant study heterogeneity [25], then the random-effects model would be performed to calculate the pooled estimates, otherwise a fixed-effect model would be carried out for the meta-analysis. The diagnostic accuracy of four PET/CT radiotracers was evaluated by several measures including the sensitivity, specificity, positive likelihood ratio-PLR, negative likelihood ratio-NLR, diagnostic odds ratio and AUC. Summary receiver operating characteristics (SROC) curves were generated to present parameter estimates using the method of inverse variance. Besides that, subgroup analyses by ethnicity and type of PET/CT were conducted to explore the potential source of heterogeneity. Publication bias of the included studies was assessed by Deeks' Funnel Plot and symmetry test which indicated significant publication bias if $P$ value was less than 0.1. We performed all statistical analysis by STATA12.0 (StataCorp, College Station, Texas).

\section{Results}

\section{Included studies}

A total of 1,313 studies were identified during the stage of initial search, 326 of the articles were eliminated for duplicate data and 637 studies were judged as unavailable by screening their titles and abstracts. The rest of 385 studies were read for full-text review. Finally, 56 studies containing 3,586 patients were included according to the inclusion and exclusion criteria. The entire process of the literature search was presented in Fig. 1.

Study populations and their characteristics were summarized in Table 1. QUADAS-2 scores indicated that all of the admitted studies were reliable with scores ranging from 6 to 9 out of 10. The included studies were reported in different countries, of those, 42 studies were performed in Europe, 7 in Asia, and 7 in Australia. In total, there were 3,743 patients as the case group and 3,586 matched healthy people as the control group. All included studies were published between 2005 and 2015 (11C-choline: $\mathrm{n}=31$ [26-54], 18F-FCH: $\mathrm{n}=15$ [17, 55-68], 11C-acetate: $\mathrm{n}=5$ [69-73], 18F-FDG: $\mathrm{n}=5$ [74-78]).

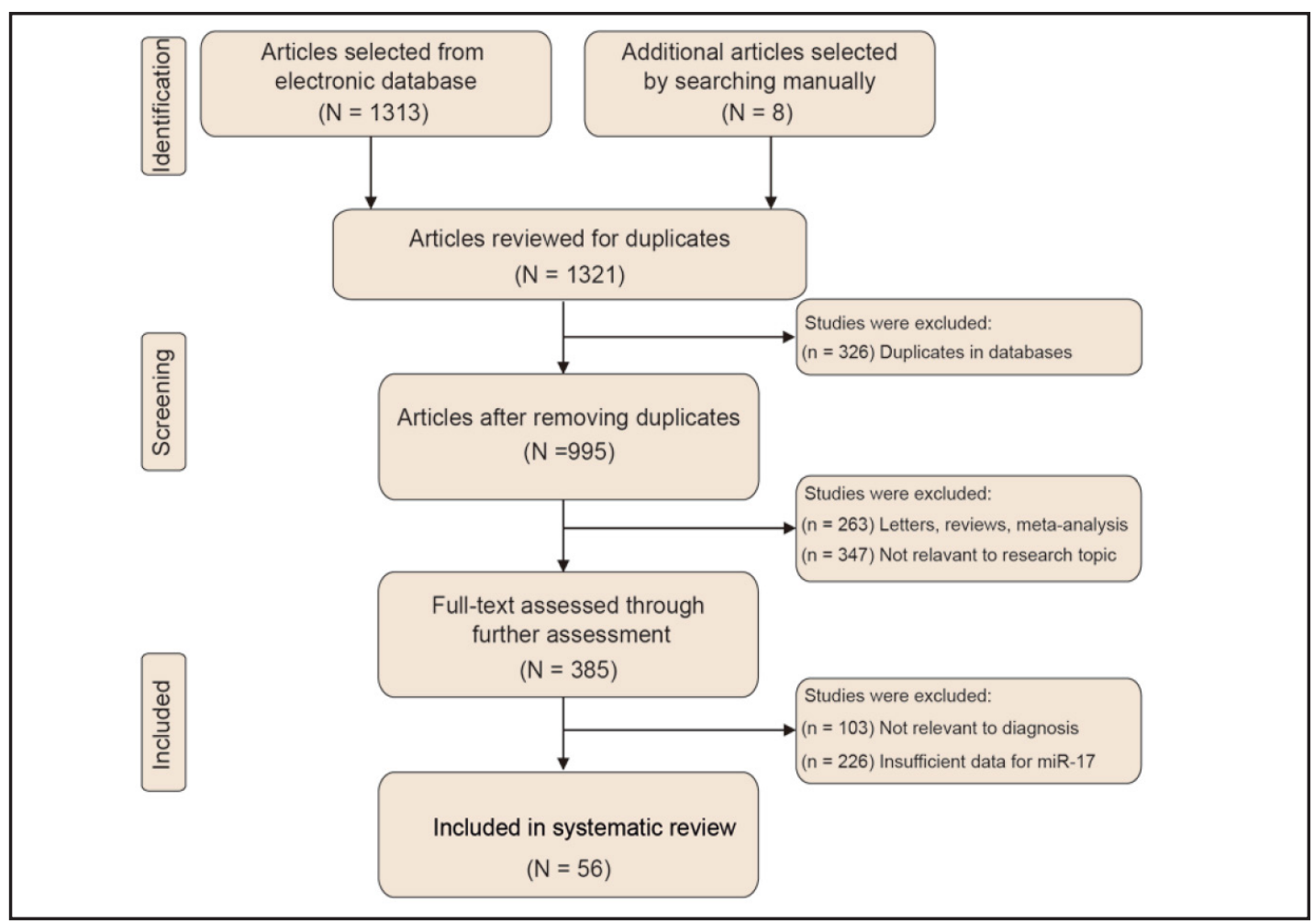

Fig. 1. Literature selection flow chart. 
Liu et al.: PET/CT for PCa diagnosis

Table 2. The pooled diagnostic performance related with 4 imaging techniques based on meta-analyses

\begin{tabular}{lcccccc}
\hline Analysis & SEN $(95 \% \mathrm{CI})$ & SPE $(95 \% \mathrm{CI})$ & PLR $(95 \% \mathrm{CI})$ & NLR $(95 \% \mathrm{CI})$ & DOR $(95 \% \mathrm{CI})$ & AUC $(95 \% \mathrm{CI})$ \\
\hline Ethnicity & & & & & & \\
Asian & $0.71(0.60,0.80)$ & $0.74(0.56,0.86)$ & $2.7(1.5,4.8)$ & $0.39(0.27,0.57)$ & $7(3,16)$ & $0.77(0.74,0.81)$ \\
Caucasian & $0.81(0.74,0.87)$ & $0.85(0.78,0.90)$ & $5.5(3.7,8.1)$ & $0.22(0.16,0.30)$ & $25(15,42)$ & $0.90(0.87,0.92)$ \\
Type of PET/CT & & & & & & \\
11C-choline PET/CT & $0.83(0.77,0.88)$ & $0.82(0.73,0.88)$ & $4.50(3.0,6.8)$ & $0.21(0.16,0.28)$ & $22(13,37)$ & $0.89(0.86,0.91)$ \\
18F-FCH PET/CT & $0.76(0.49,0.91)$ & $0.93(0.84,0.97)$ & $11.70(4.9,27.9)$ & $0.26(0.10,0.63)$ & $46(13,165)$ & $0.94(0.92,0.96)$ \\
11C-acetate PET/CT & $0.79(0.70,0.86)$ & $0.59(0.43,0.73)$ & $1.90(1.4,2.7)$ & $0.35(0.25,0.49)$ & $6(3,10)$ & $0.78(0.74,0.81)$ \\
18F-FDG PET/CT & $0.67(0.55,0.77)$ & $0.72(0.50,0.87)$ & $2.40(1.3,4.5)$ & $0.46(0.34,0.6)$ & $5(2,12)$ & $0.73(0.69,0.77)$ \\
Overall & $0.80(0.74,0.85)$ & $0.84(0.77,0.89)$ & $5.0(3.5,7.1)$ & $0.23(0.18,0.31)$ & $21(13,34)$ & $0.89(0.86,0.91)$ \\
\hline
\end{tabular}

CI: confidence interval; SEN: sensitivity; SPE: specificity; PLR: positive likelihood ratio; NLR: negative likelihood ratio; DOR: diagnostic odds ratio; AUC: area under the curve.

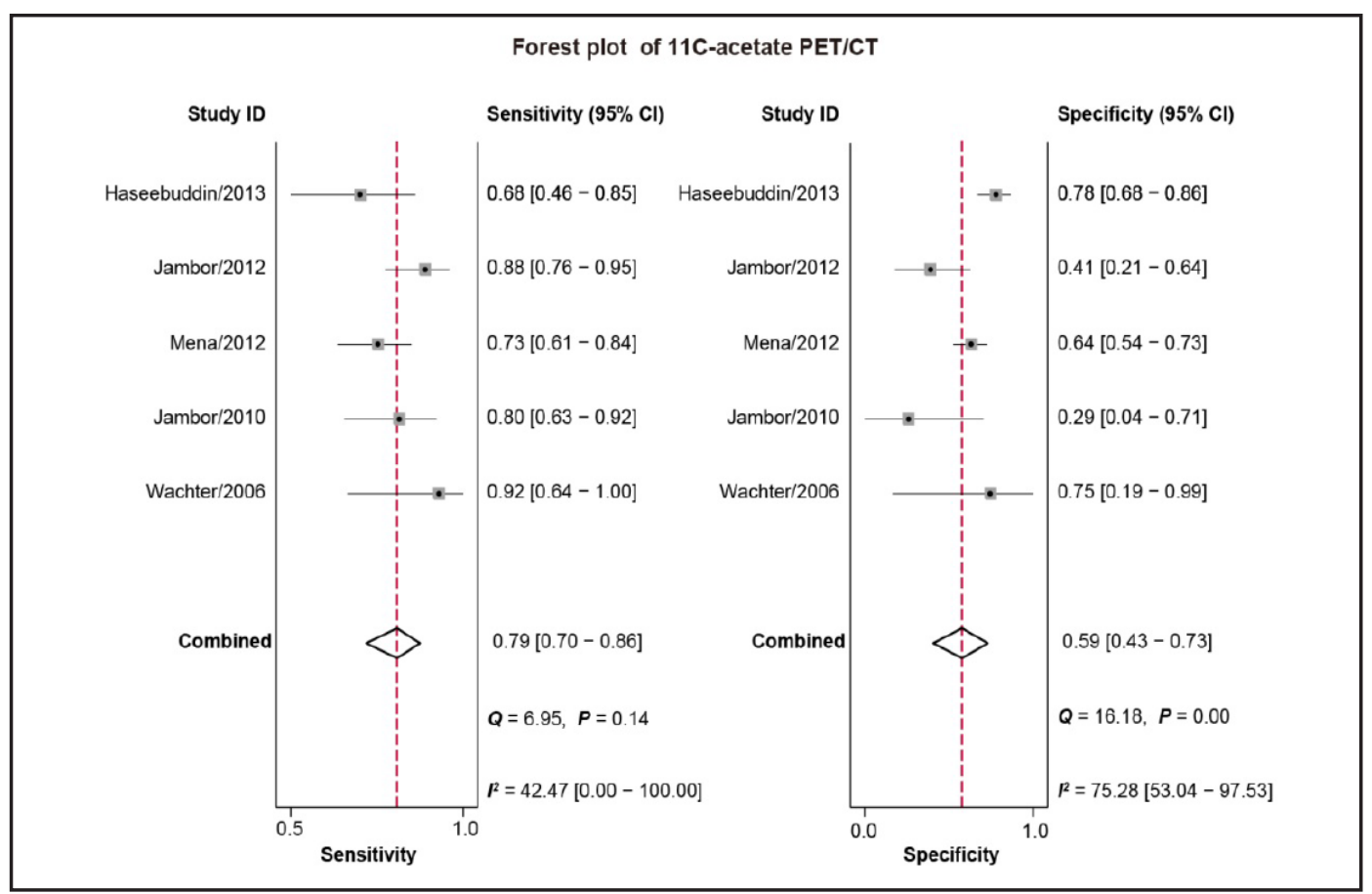

Fig. 2. Forest plots of sensitivity and specificity for 11C-acetate PET/CT.

\section{Summary of the diagnostic performance}

First of all, test of heterogeneity was performed to assess whether the included studies were homogeneous and then the pooled diagnostic statistics were evaluated. $I^{2}$ values for sensitivity and specificity was $90.24 \%$ (95\% CI: 88.31-92.16\%, $P<0.001$ ) and 95.60\% (95\% CI: 94.91-96.28\%, $P<0.001$ ), respectively. A random-effects model was adopted to assess the pooled data due to the existence of significant heterogeneity among studies. As suggested by Table 2, the overall parameter estimates are as follows: sensitivity, 0.80 (95\% CI: 0.740.85); specificity, 0.84 (95\% CI: 0.77-0.89); PLR, 5.0 (95\% CI: 3.5-7.1); NLR, 0.23 (95\% CI: 0.18-0.31); and DOR, 21 (95\% CI: 13-34). The pooled AUC was 0.89 (95\% CI: 0.86-0.91), suggesting a relatively high level of accuracy for PCa diagnosis by PET/CT.

\section{Subgroup analysis}

Subgroup analysis by types of PET/CT was performed to assess whether there was significant heterogeneity among the four PET/CT radiotracers in respect of diagnostic accuracy. We implemented a random-effects model for 11C-PET/CT, 18F-FCH-PET/CT and 18F-FDG due to the presence of significant heterogeneity $\left(I^{2}>50 \%, P<0.001\right)$ (Fig. 2-5). 


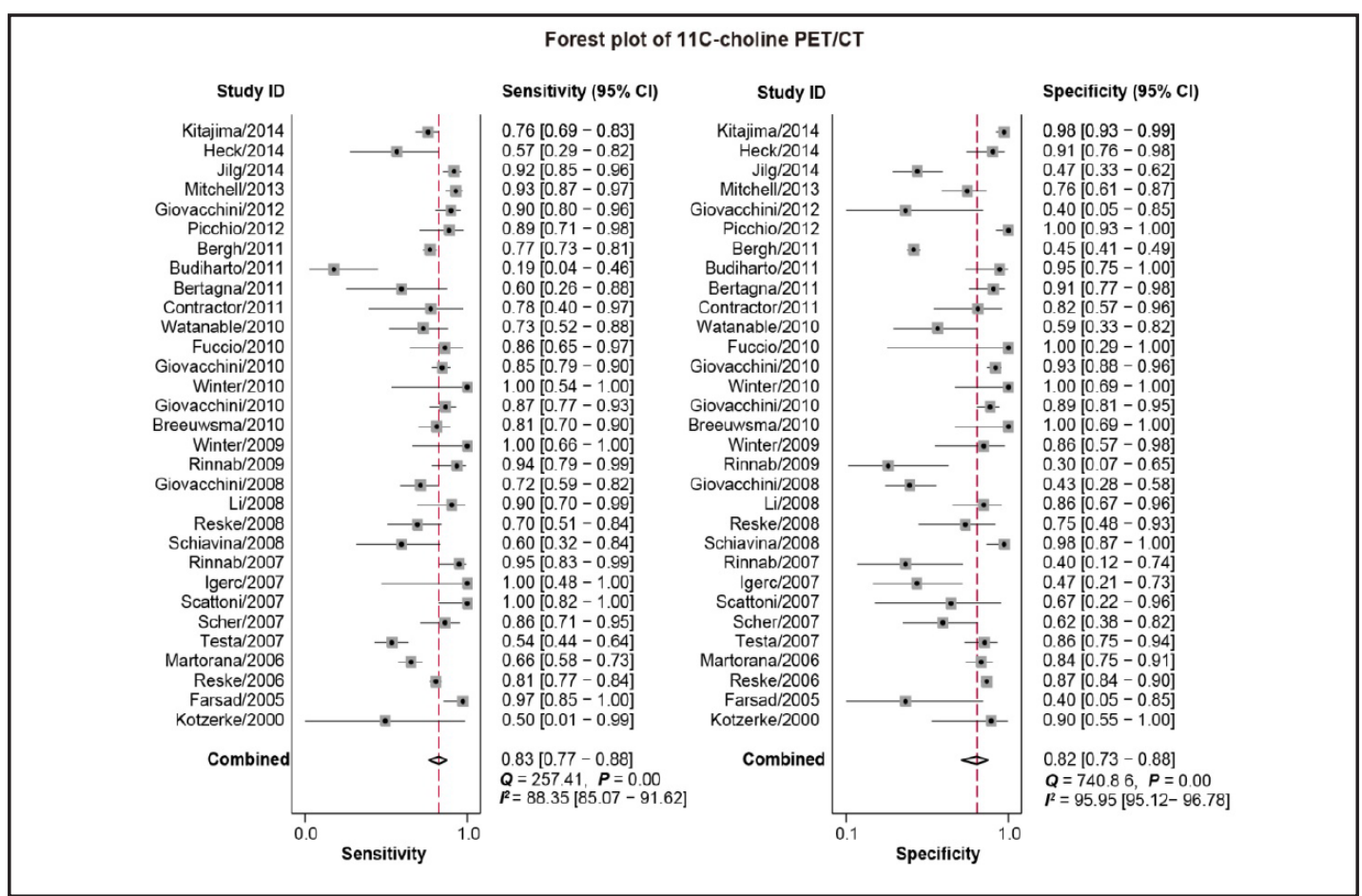

Fig. 3. Forest plots of sensitivity and specificity for 11C-choline PET/CT.

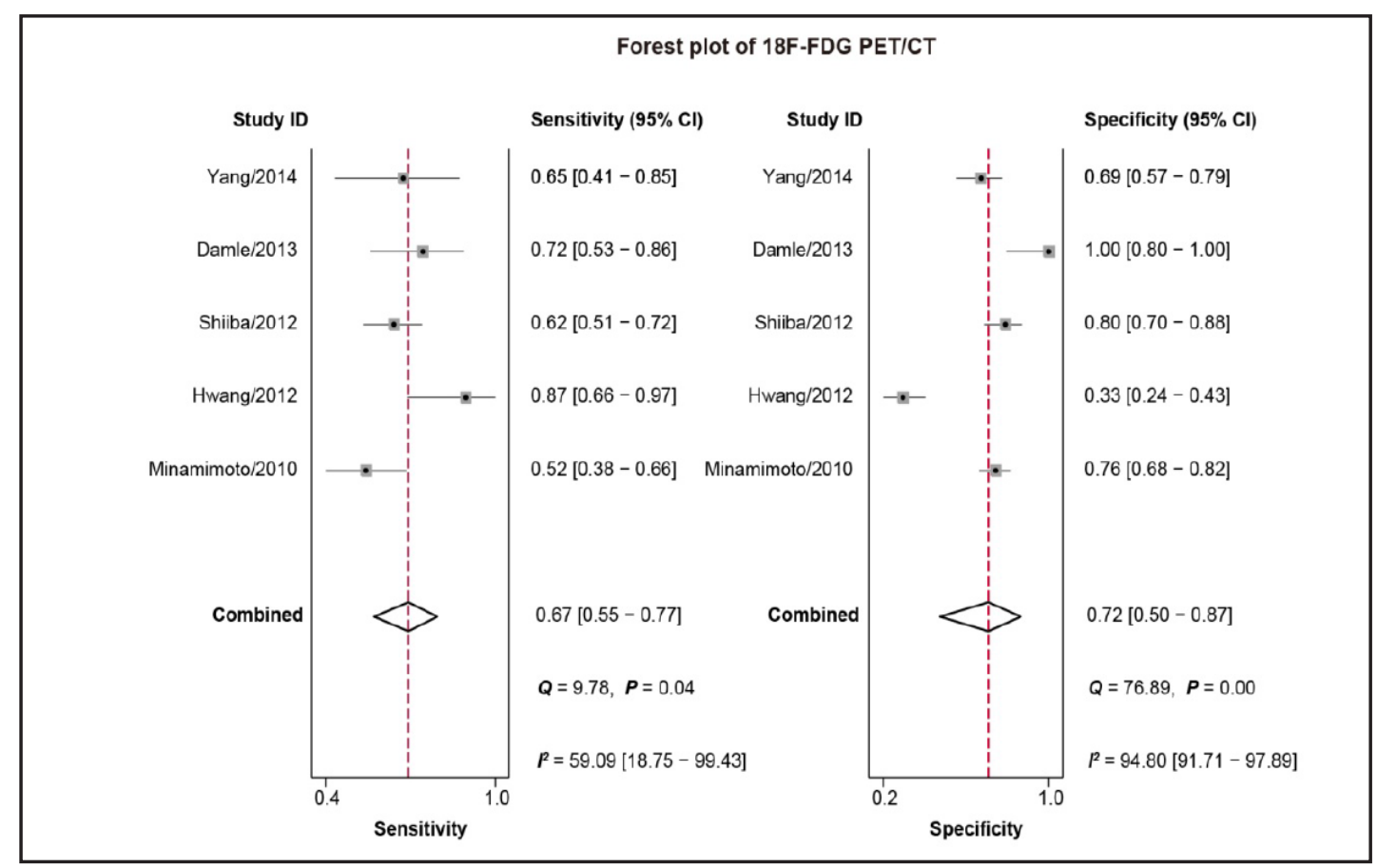

Fig. 4. Forest plots of sensitivity and specificity for 18F-FDG PET/CT.

By contrast, a fixed-effect model was adopted for the sensitivity of 11C-acetate PET/CT $\left(I^{2}\right.$ $=42.47, P=0.140$ ). The pooled sensitivities of the four diagnostic techniques were ordered in a descending order: 11C-PET $/$ CT (sensitivity $=0.83 ; 95 \% \mathrm{CI}$ : 0.770-0.88), 11C-Acetate PET $/$ CT (sensitivity $=0.79 ; 95 \%$ CI: 0.70-0.86), 18F-FCH-PET $/$ CT $($ sensitivity $=0.76 ; 95 \%$ CI: 0.49-0.91), 18F-FDG PET/CT (sensitivity $=0.67 ; 95 \%$ CI: 0.55-0.77). Moreover, 18F-FCH$\mathrm{PET} / \mathrm{CT}$ had the highest specificity (specificity $=0.93 ; 95 \% \mathrm{CI}=0.84-0.97$ ) followed 


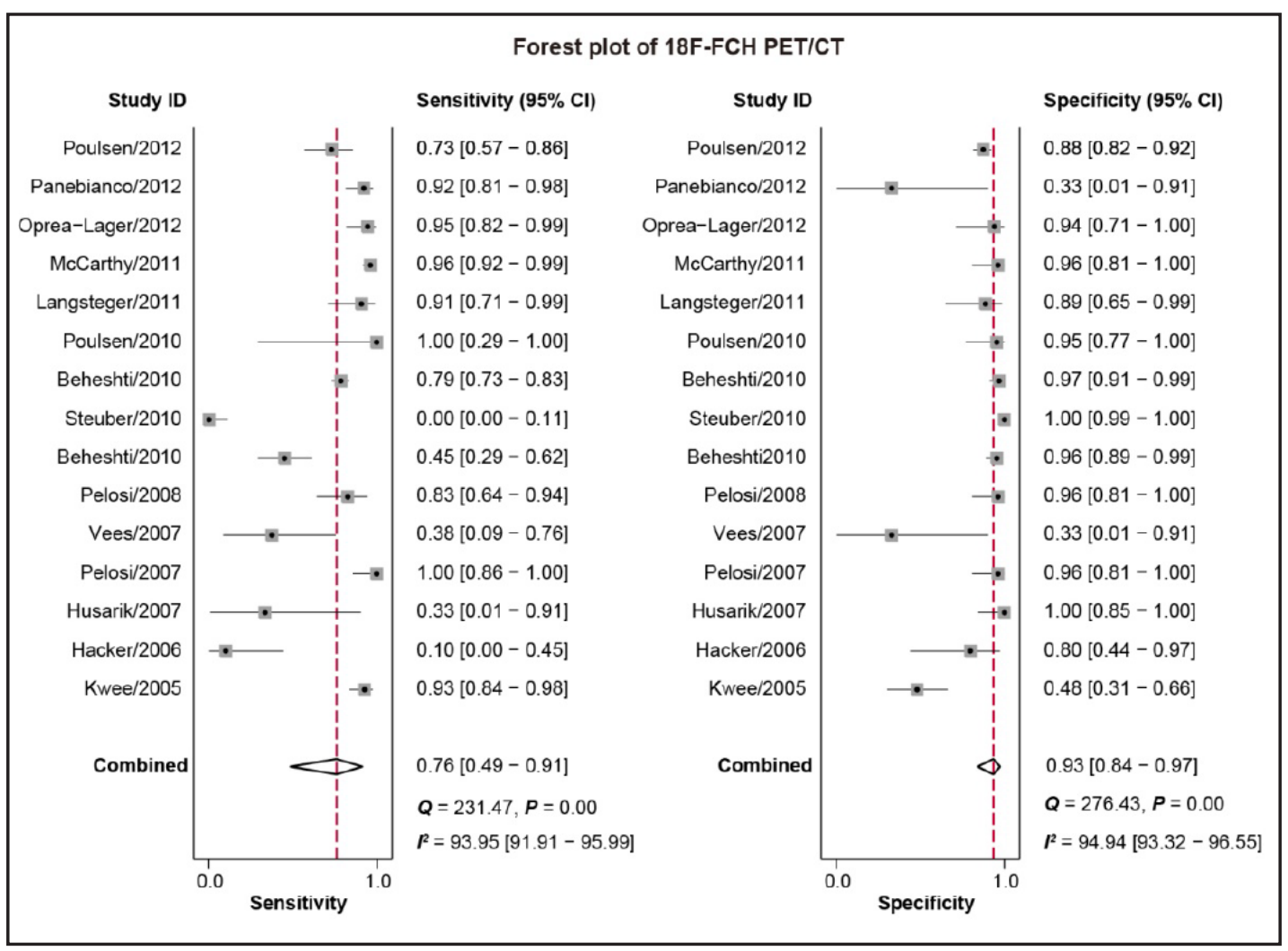

Fig. 5. Forest plots of sensitivity and specificity for 18F-FCH PET/CT.

11C-PET $/$ CT (specificity $=0.82,95 \%$ CI: 0.73-0.88), 18F-FDG PET $/$ CT $($ specificity $=0.72$; 95\% CI: 0.50-0.87) and 11C-Acetate PET/CT (specificity $=0.59 ; 95 \%$ CI: 0.43-0.73). Besides that, 18F-FCH-PET/CT had the highest AUC (AUC $=0.94 ; 95 \%$ CI: 0.92-0.96) followed by 11C-PET $/$ CT $($ AUC $=0.89,95 \%$ CI: 0.86-0.91), 11C-Acetate PET $/$ CT $($ AUC $=0.78,95 \%$ CI: 0.74-0.81) and 18F-FDG PET/CT (AUC = 0.73, 95\% CI: 0.69-0.77) (Fig. 6).

Table 2 also revealed the pooled diagnostic results obtained from subgroup analysis by ethnicity. The diagnostic accuracy in Caucasian was higher (sensitivity $=0.81,95 \%$ CI: 0.74 0.87 ; specificity $=0.85,95 \% \mathrm{CI}: 0.78-0.90 ; \mathrm{AUC}=0.90,95 \% \mathrm{CI}: 0.87-0.92$ ) compared to that in Asian (sensitivity $=0.71,95 \%$ CI: $0.60-0.80$, specificity $=0.74,95 \%$ CI: $0.56-0.86$; AUC $=0.77$, 95\% CI: 0.74-0.81). The corresponding SROC curve was showed in Fig. 7.

\section{Discussion}

PET/CT has been developed as a new technology to improve the accuracy of clinical molecular imaging, especially for phymatology [7]. Moreover, the development of PET/CT radiotracers is critical to the early diagnosis of cancer which may enhance the chance of survival for cancer patients. Major radiotracers including 18F-FDG, 11C-choline, 18F-FCH and $11 \mathrm{C}$-acetate enabled us to visualize tumor metabolisms and hence precisely assess the stage of cancer. As one of the first radiotracers, 18F-FDG is associated with low sensitivity and specificity especially in diagnosing well-differentiated PCa as its diagnostic accuracy is related to urinary excretion. Hence, 18F-FDG has limited performance on PCa diagnosis [10]. Other PET radiotracers, such as 18F-FCH, 11C-choline and 11C-acetate have been recommended and encouraging results were obtained [79-84]. Although, a systematic review has investigated the application of 18F-FCH PET/CT in PCa diagnosis [85], these recommendations remained unclear and the overall diagnostic performance remained vague. 


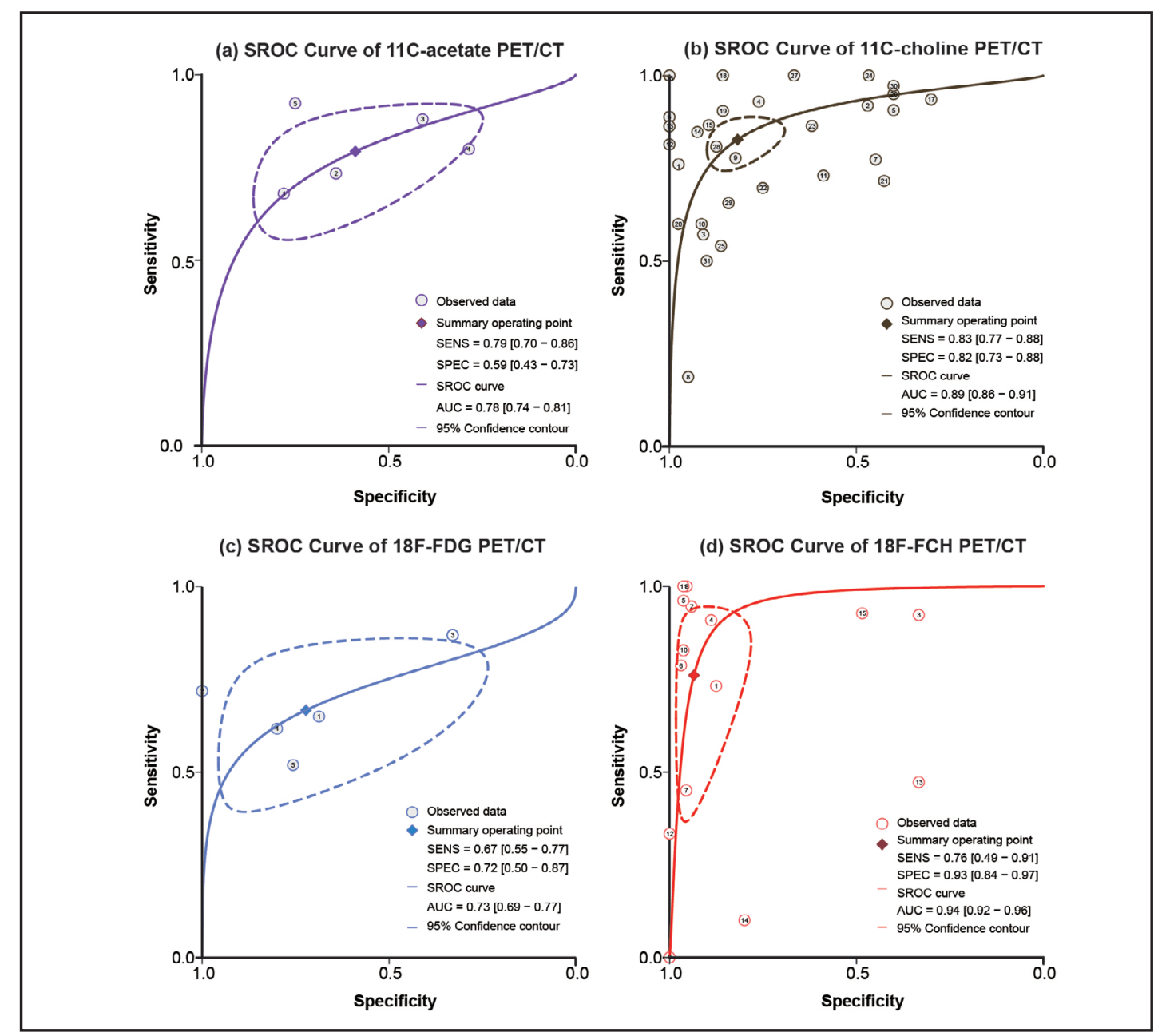

Fig. 6. SROC curves of four PET/CT radiotracers, a: 11C-acetate PET/CT; b: 11C-choline PET/CT; c: 18F-FDG PET/CT; d: 18F-FCH PET/CT.

Therefore, the diagnostic accuracy of the four radiotracers in PET/ CT were compared and assessed in this meta-analysis in order to address the issue of inconsistency resulted from study heterogeneity.

Our study indicated that 11C-acetate was more accurate than 18F-FDG with respect to the diagnostic accuracy of $\mathrm{PCa}$ and this was consistent with those results from previous studies [81, 86]. The diagnostic superiority of $11 \mathrm{C}$-acetate over 18F-FDG may be explained by several facts. Firstly, 18F-FDG was mainly excreted through kidneys, urinary bladder and urethra which may result in the obscure of the urinary bladder. On the contrary, 11C-carbon dioxide

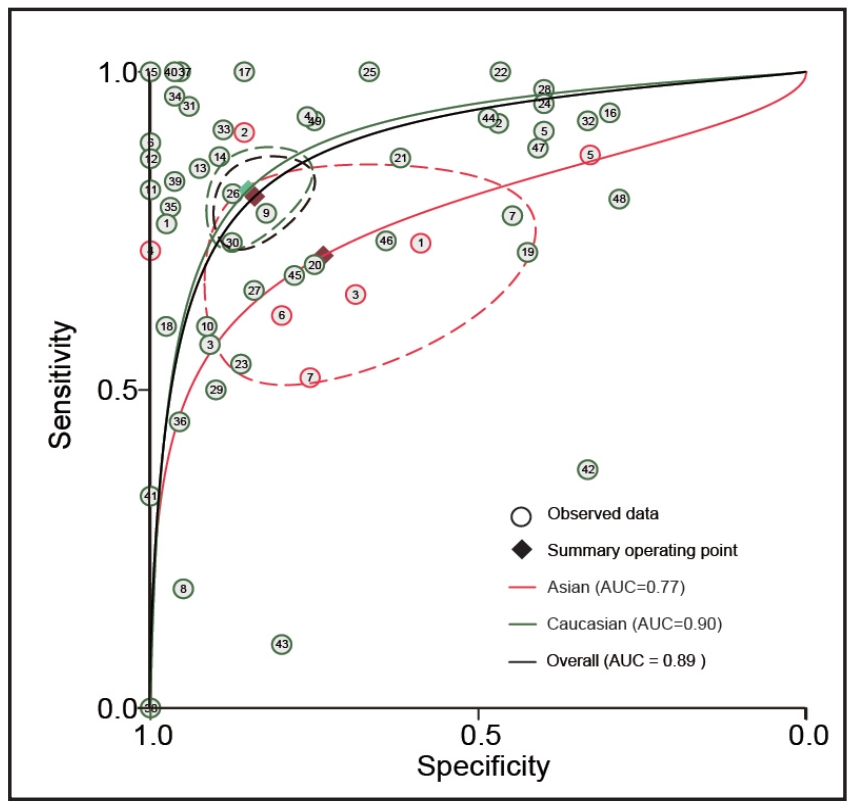

Fig. 7. SROC curves of overall and subgroup by ethnicity.

\section{KARGER}


which is the primary metabolite of $11 \mathrm{C}$-acetate rapidly exhales through the respiratory system and the remaining $11 \mathrm{C}$-acetate filtered through kidney are almost negligible. Hence, the visualization of PCa tissues is not interfered with the elimination of 11C-acetate, especially for regional lymph node metastasis and local recurrence PCa. Indeed, 11C-acetate could contribute to prostate-specific citrate metabolism which may be beneficial to tumor detection for localized PCa [81].

Both 18F-FCH and 11C-cholineare choline PET/CT and the result indicated that they were significantly better than $11 \mathrm{C}$-acetate. Since choline is an important component in synthesizing phospholipids, the activity of choline has substantial influence on the activity of the enzyme choline kinase and PCa cell proliferation. Therefore, an elevated activity of choline and kinase could be detected in malignant cells [87]. Moreover, the promising results were also obtained in the preoperative staging of pelvic lymph nodes for PCa patients [84]. However, 11C-choline radiotracers have a relatively short half-life which could be overcome by $18 \mathrm{~F}-\mathrm{FCH}$. Hence, $18 \mathrm{~F}-\mathrm{FCH}$ seems to be more accurate than $11 \mathrm{C}$-choline in respect of PCa diagnosis $[88,89]$.

Subgroup analysis by ethnicity revealed that Caucasian population (AUC $=0.90)$ had significantly higher diagnostic accuracy than Asian (AUC $=0.77)$. The significant diagnostic difference between the two ethnicities may be attributable to the fact that almost all of the Asian populations in our study were diagnosed by18-FDG whose diagnosis efficiency was relatively low.

Despite of the innovation and potential advantages in our meta-analysis, certain limitations still existed. First of all, the synthesized results were not applicable to other ethnicity since there were no African populations involved in our study. Secondly, subgroup analysis by radiotracers was not feasible due to insufficient data. Thirdly, some potential factors that affect the diagnostic accuracy of PCa were not assessed due to the clinical and biological complexity of PCa. For instance, the diagnostic accuracy is likely to be affected by different clinical stages of $\mathrm{PCa}$, including locally recurrent, metastatic and loco regional lymph nodes PCa and this kind of information was not available. In addition, the absence of a thorough histopathological analysis for tumor tissues further reduces the credibility of the results.

For summary, our meta-analysis assessed four radiotracers employed in PET/CT for PCa detection. The results obtained from this study suggested that PET/CT imaging plays an irreplaceable role in PCa diagnosis. Among the four radiotracers, Choline PET/CT particularly 18F-FCH PET/CT were more favorable than others in respect of PCa diagnostic accuracy. Still, we strongly recommended that future studies which are applicable to all ethnicities and adjusted for potential confounding factors should be designed to confirm our conclusion.

\section{Disclosure Statement}

The authors declare no commercial or financial conflict of interest.

\section{References}

1 Luo G, Wang M, Wu X, Tao D, Xiao X, Wang L, Min F, Zeng F, Jiang G: Long Non-Coding RNA MEG3 Inhibits Cell Proliferation and Induces Apoptosis in Prostate Cancer. Cell Physiol Biochem 2015;37:2209-2220.

2 Torre LA, Bray F, Siegel RL, Ferlay J, Lortet-Tieulent J, Jemal A: Global cancer statistics, 2012. CA Cancer J Clin 2015;65:87-108.

3 Young B, Purcell C, Kuang YQ Charette N, Dupre DJ: Superoxide Dismutase 1 Regulation of CXCR4Mediated Signaling in Prostate Cancer Cells is Dependent on Cellular Oxidative State. Cell Physiol Biochem 2015;37:2071-2084.

4 Beresford MJ, Gillatt D, Benson RJ, Ajithkumar T: A systematic review of the role of imaging before salvage radiotherapy for post-prostatectomy biochemical recurrence. Clin Oncol (R Coll Radiol) 2010;22:46-55. 
5 Ravizzini G, Turkbey B, Kurdziel K, Choyke PL: New horizons in prostate cancer imaging. Eur J Radiol 2009;70:212-226.

6 Picchio M, Crivellaro C, Giovacchini G, Gianolli L, Messa C: PET-CT for treatment planning in prostate cancer. Q J Nucl Med Mol Imaging 2009;53:245-268.

7 Townsend DW: Dual-modality imaging: combining anatomy and function. J Nucl Med 2008;49:938-955.

8 Powles T, Murray I, Brock C, Oliver T, Avril N: Molecular positron emission tomography and PET/CT imaging in urological malignancies. Eur Urol 2007;51:1511-1520; discussion 1520-1511.

9 von Mallek D, Backhaus B, Muller SC, Matthies A, Palmedo H, Jaeger U, Biersack HJ, Reinhardt M: [Technical limits of PET/CT with 18FDG in prostate cancer]. Aktuelle Urol 2006;37:218-221.

10 Jadvar H: Molecular imaging of prostate cancer with 18F-fluorodeoxyglucose PET. Nat Rev Urol 2009;6:317-323.

11 Avril N, Dambha F, Murray I, Shamash J, Powles T, Sahdev A: The clinical advances of fluorine-2-Ddeoxyglucose--positron emission tomography/computed tomography in urological cancers. Int J Urol 2010;17:501-511.

12 Wang X, Koch S: Positron emission tomography/computed tomography potential pitfalls and artifacts. Curr Probl Diagn Radiol 2009;38:156-169.

13 Bouchelouche K, Oehr P: Positron emission tomography and positron emission tomography/computerized tomography of urological malignancies: an update review. J Urol 2008;179:34-45.

14 Richter JA, Rodriguez M, Rioja J, Penuelas I, Marti-Climent J, Garrastachu P, Quincoces G, Zudaire J, GarciaVelloso MJ: Dual tracer 11C-choline and FDG-PET in the diagnosis of biochemical prostate cancer relapse after radical treatment. Mol Imaging Biol 2010;12:210-217.

15 Zeisel SH: Dietary choline: biochemistry, physiology, and pharmacology. Annu Rev Nutr 1981;1:95-121.

16 Rumsby M, Schmitt J, Sharrard M, Rodrigues G, Stower M, Maitland N: Human prostate cell lines from normal and tumourigenic epithelia differ in the pattern and control of choline lipid headgroups released into the medium on stimulation of protein kinase C. Br J Cancer 2011;104:673-684.

17 Pelosi E, Arena V, Skanjeti A, Pirro V, Douroukas A, Pupi A, Mancini M: Role of whole-body 18F-choline PET/ $\mathrm{CT}$ in disease detection in patients with biochemical relapse after radical treatment for prostate cancer. Radiol Med 2008;113:895-904.

18 de Jong IJ, Pruim J, Elsinga PH, Vaalburg W, Mensink HJ: Visualization of prostate cancer with 11C-choline positron emission tomography. Eur Urol 2002;42:18-23.

19 Leung K: [11C]Acetate. Molecular Imaging and Contrast Agent Database (MICAD). Bethesda (MD) 2004.

20 Grassi I, Nanni C, Allegri V, Morigi JJ, Montini GC, Castellucci P, Fanti S: The clinical use of PET with (11) C-acetate. Am J Nucl Med Mol Imaging 2012;2:33-47.

21 Swinnen JV, Roskams T, Joniau S, Van Poppel H, Oyen R, Baert L, Heyns W, Verhoeven G: Overexpression of fatty acid synthase is an early and common event in the development of prostate cancer. Int J Cancer 2002;98:19-22.

22 Mohsen B, Giorgio T, Rasoul ZS, Werner L, Ali GR, Reza DK, Ramin S: Application of C-11-acetate positronemission tomography (PET) imaging in prostate cancer: systematic review and meta-analysis of the literature. BJU Int 2013;112:1062-1072.

23 Mena E, Turkbey B, Mani H, Adler S, Valera VA, Bernardo M, Shah V, Pohida T, McKinney Y, Kwarteng G, Daar D, Lindenberg ML, Eclarinal P, Wade R, Linehan WM, Merino MJ, Pinto PA, Choyke PL, Kurdziel KA: 11C-Acetate PET/CT in localized prostate cancer: a study with MRI and histopathologic correlation. J Nucl Med 2012;53:538-545.

24 Whiting PF, Rutjes AW, Westwood ME, Mallett S, Deeks JJ, Reitsma JB, Leeflang MM, Sterne JA, Bossuyt PM: QUADAS-2: a revised tool for the quality assessment of diagnostic accuracy studies. Ann Intern Med 2011;155:529-536.

25 Higgins JP, Thompson SG, Deeks JJ, Altman DG: Measuring inconsistency in meta-analyses. BMJ 2003;327:557-560.

26 Kitajima K, Murphy RC, Nathan MA, Froemming AT, Hagen CE, Takahashi N, Kawashima A: Detection of recurrent prostate cancer after radical prostatectomy: comparison of 11C-choline PET/CT with pelvic multiparametric MR imaging with endorectal coil. J Nucl Med 2014;55:223-232. 


\section{Cellular Physiology Cell Physiol Biochem 2016;39:467-480 \begin{tabular}{l|l|l} 
DOI: 10.1159/000445639 & $\begin{array}{l}\text { O 2016 The Author(s). Published by S. Karger AG, Basel } \\
\text { www.karger.com/cpb }\end{array}$ \\
\cline { 2 - 3 }
\end{tabular}}

Liu et al.: PET/CT for PCa diagnosis

27 Jilg CA, Schultze-Seemann W, Drendel V, Vach W, Wieser G, Krauss T, Jandausch A, Holz S, Henne K, Reske SN, Grosu AL, Weber WA, Rischke HC: Detection of lymph node metastasis in patients with nodal prostate cancer relapse using (18)F/(11)C-choline positron emission tomography/computerized tomography. J Urol 2014;192:103-110.

28 Heck MM, Souvatzoglou M, Retz M, Nawroth R, Kubler H, Maurer T, Thalgott M, Gramer BM, Weirich G, Rondak IC, Rummeny EJ, Schwaiger M, Gschwend JE, Krause B, Eiber M: Prospective comparison of computed tomography, diffusion-weighted magnetic resonance imaging and [11C]choline positron emission tomography/computed tomography for preoperative lymph node staging in prostate cancer patients. Eur J Nucl Med Mol Imaging 2014;41:694-701.

29 Mitchell CR, Lowe VJ, Rangel LJ, Hung JC, Kwon ED, Karnes RJ: Operational characteristics of (11) c-choline positron emission tomography/computerized tomography for prostate cancer with biochemical recurrence after initial treatment. J Urol 2013;189:1308-1313.

30 Giovacchini G, Picchio M, Garcia-Parra R, Mapelli P, Briganti A, Montorsi F, Gianolli L, Messa C: [11C] choline positron emission tomography/computerized tomography for early detection of prostate cancer recurrence in patients with low increasing prostate specific antigen. J Urol 2013;189:105-110.

31 Picchio M, Spinapolice EG, Fallanca F, Crivellaro C, Giovacchini G, Gianolli L, Messa C: [11C]Choline PET/CT detection of bone metastases in patients with PSA progression after primary treatment for prostate cancer: comparison with bone scintigraphy. Eur J Nucl Med Mol Imaging 2012;39:13-26.

32 Budiharto T, Joniau S, Lerut E, Van den Bergh L, Mottaghy F, Deroose CM, Oyen R, Ameye F, Bogaerts K, Haustermans K, Van Poppel H: Prospective evaluation of 11C-choline positron emission tomography/ computed tomography and diffusion-weighted magnetic resonance imaging for the nodal staging of prostate cancer with a high risk of lymph node metastases. Eur Urol 2011;60:125-130.

33 Contractor K, Challapalli A, Barwick T, Winkler M, Hellawell G, Hazell S, Tomasi G, Al-Nahhas A, Mapelli P, Kenny LM, Tadrous P, Coombes RC, Aboagye EO, Mangar S: Use of [11C]choline PET-CT as a noninvasive method for detecting pelvic lymph node status from prostate cancer and relationship with choline kinase expression. Clin Cancer Res 2011;17:7673-7683.

34 Bertagna F, Abuhilal M, Bosio G, Simeone C, Rossini P, Pizzocaro C, Orlando E, Finamanti M, Biasiotto G, Rodella C, Cosciani Cunico S, Giubbini R: Role of (1)(1)C-choline positron emission tomography/computed tomography in evaluating patients affected by prostate cancer with suspected relapse due to prostatespecific antigen elevation. Jpn J Radiol 2011;29:394-404.

35 Watanabe H, Kanematsu M, Kondo H, Kako N, Yamamoto N, Yamada T, Goshima S, Hoshi H, Bae KT: Preoperative detection of prostate cancer: a comparison with 11C-choline PET, 18F-fluorodeoxyglucose PET and MR imaging. J Magn Reson Imaging 2010;31:1151-1156.

36 Breeuwsma AJ, Pruim J, van den Bergh AC, Leliveld AM, Nijman RJ, Dierckx RA, de Jong IJ: Detection of local, regional, and distant recurrence in patients with psa relapse after external-beam radiotherapy using (11) C-choline positron emission tomography. Int J Radiat Oncol Biol Phys 2010;77:160-164.

37 Fuccio C, Schiavina R, Castellucci P, Rubello D, Martorana G, Celli M, Malizia C, Profitos MB, Marzola MC, Pettinato V, Fanti S: Androgen deprivation therapy influences the uptake of 11C-choline in patients with recurrent prostate cancer: the preliminary results of a sequential PET/CT study. Eur J Nucl Med Mol Imaging 2011;38:1985-1989.

38 Giovacchini G, Picchio M, Scattoni V, Garcia Parra R, Briganti A, Gianolli L, Montorsi F, Messa C: PSA doubling time for prediction of $[(11) \mathrm{C}]$ choline PET/CT findings in prostate cancer patients with biochemical failure after radical prostatectomy. Eur J Nucl Med Mol Imaging 2010;37:1106-1116.

39 Giovacchini G, Picchio M, Coradeschi E, Bettinardi V, Gianolli L, Scattoni V, Cozzarini C, Di Muzio N, Rigatti P, Fazio F, Messa C: Predictive factors of [(11)C]choline PET/CT in patients with biochemical failure after radical prostatectomy. Eur J Nucl Med Mol Imaging 2010;37:301-309.

40 Winter A, Uphoff J, Henke RP, Wawroschek F: First results of [11C]choline PET/CT-guided secondary lymph node surgery in patients with PSA failure and single lymph node recurrence after radical retropubic prostatectomy. Urol Int 2010;84:418-423.

41 Rinnab L, Simon J, Hautmann RE, Cronauer MV, Hohl K, Buck AK, Reske SN, Mottaghy FM: [(11)C]choline PET/CT in prostate cancer patients with biochemical recurrence after radical prostatectomy. World J Urol 2009;27:619-625. 
42 Winter A, Uphoff J, Henke RP, Wawroschek F: [First results of PET / CT-guided secondary lymph node surgery on patients with a PSA relapse after radical prostatectomy]. Aktuelle Urol 2009;40:294-299.

43 Li X, Liu Q Wang M, Jin X, Yao S, Liu S, Li J: C-11 choline PET/CT imaging for differentiating malignant from benign prostate lesions. Clin Nucl Med 2008;33:671-676.

44 Giovacchini G, Picchio M, Coradeschi E, Scattoni V, Bettinardi V, Cozzarini C, Freschi M, Fazio F, Messa C: $[(11) \mathrm{C}]$ choline uptake with PET/CT for the initial diagnosis of prostate cancer: relation to PSA levels, tumour stage and anti-androgenic therapy. Eur J Nucl Med Mol Imaging 2008;35:1065-1073.

45 Schiavina R, Scattoni V, Castellucci P, Picchio M, Corti B, Briganti A, Franceschelli A, Sanguedolce F, Bertaccini A, Farsad M, Giovacchini G, Fanti S, Grigioni WF, Fazio F, Montorsi F, Rigatti P, Martorana G: 11C-choline positron emission tomography/computerized tomography for preoperative lymph-node staging in intermediate-risk and high-risk prostate cancer: comparison with clinical staging nomograms. Eur Urol 2008;54:392-401.

46 Reske SN, Blumstein NM, Neumaier B, Gottfried HW, Finsterbusch F, Kocot D, Moller P, Glatting G, Perner S: Imaging prostate cancer with 11C-choline PET/CT. J Nucl Med 2006;47:1249-1254.

47 Scher B, Seitz M, Albinger W, Tiling R, Scherr M, Becker HC, Souvatzogluou M, Gildehaus FJ, Wester HJ, Dresel S: Value of 11C-choline PET and PET/CT in patients with suspected prostate cancer. Eur J Nucl Med Mol Imaging 2007;34:45-53.

48 Igerc I, Kohlfurst S, Gallowitsch HJ, Matschnig S, Kresnik E, Gomez-Segovia I, Lind P: The value of 18F-choline PET/CT in patients with elevated PSA-level and negative prostate needle biopsy for localisation of prostate cancer. Eur J Nucl Med Mol Imaging 2008;35:976-983.

49 Testa C, Schiavina R, Lodi R, Salizzoni E, Corti B, Farsad M, Kurhanewicz J, Manferrari F, Brunocilla E, Tonon C, Monetti N, Castellucci P, Fanti S, Coe M, Grigioni WF, Martorana G, Canini R, Barbiroli B: Prostate cancer: sextant localization with MR imaging, MR spectroscopy, and 11C-choline PET/CT. Radiology 2007;244:797806.

50 Scattoni V, Picchio M, Suardi N, Messa C, Freschi M, Roscigno M, Da Pozzo L, Bocciardi A, Rigatti P, Fazio F: Detection of lymph-node metastases with integrated [11C]choline PET/CT in patients with PSA failure after radical retropubic prostatectomy: results confirmed by open pelvic-retroperitoneal lymphadenectomy. Eur Urol 2007;52:423-429.

51 Reske SN, Blumstein NM, Glatting G: [11C]choline PET/CT imaging in occult local relapse of prostate cancer after radical prostatectomy. Eur J Nucl Med Mol Imaging 2008;35:9-17.

52 Martorana G, Schiavina R, Corti B, Farsad M, Salizzoni E, Brunocilla E, Bertaccini A, Manferrari F, Castellucci P, Fanti S, Canini R, Grigioni WF, D'Errico Grigioni A: 11C-choline positron emission tomography/ computerized tomography for tumor localization of primary prostate cancer in comparison with 12-core biopsy. J Urol 2006;176:954-960; discussion 960.

53 Farsad M, Schiavina R, Castellucci P, Nanni C, Corti B, Martorana G, Canini R, Grigioni W, Boschi S, Marengo M, Pettinato C, Salizzoni E, Monetti N, Franchi R, Fanti S: Detection and localization of prostate cancer: correlation of (11)C-choline PET/CT with histopathologic step-section analysis. J Nucl Med 2005;46:16421649.

54 Kotzerke J, Prang J, Neumaier B, Volkmer B, Guhlmann A, Kleinschmidt K, Hautmann R, Reske SN: Experience with carbon-11 choline positron emission tomography in prostate carcinoma. Eur J Nucl Med 2000;27:1415-1419.

55 Poulsen MH, Bouchelouche K, Hoilund-Carlsen PF, Petersen H, Gerke O, Steffansen SI, Marcussen N, Svolgaard N, Vach W, Geertsen U, Walter S: [18F]fluoromethylcholine (FCH) positron emission tomography/computed tomography (PET/CT) for lymph node staging of prostate cancer: a prospective study of 210 patients. BJU Int 2012;110:1666-1671.

56 Oprea-Lager DE, Vincent AD, van Moorselaar RJ, Gerritsen WR, van den Eertwegh AJ, Eriksson J, Boellaard R, Hoekstra OS: Dual-phase PET-CT to differentiate [18F]Fluoromethylcholine uptake in reactive and malignant lymph nodes in patients with prostate cancer. PLoS One 2012;7:e48430.

57 Panebianco V, Sciarra A, Lisi D, Galati F, Buonocore V, Catalano C, Gentile V, Laghi A, Passariello R: Prostate cancer: 1 HMRS-DCEMR at 3T versus [(18)F]choline PET/CT in the detection of local prostate cancer recurrence in men with biochemical progression after radical retropubic prostatectomy (RRP). Eur J Radiol 2012;81:700-708. 


\section{Cellular Physiology Cell Physiol Biochem 2016;39:467-480 \begin{tabular}{l|l|l} 
DOI: 10.1159/000445639 & $\begin{array}{l}\text { O 2016 The Author(s). Published by S. Karger AG, Basel } \\
\text { www.karger.com/cpb }\end{array}$ \\
\cline { 2 - 3 } & Published online: July 07, 2016
\end{tabular}}

Liu et al.: PET/CT for PCa diagnosis

58 Langsteger W, Balogova S, Huchet V, Beheshti M, Paycha F, Egrot C, Janetschek G, Loidl W, Nataf V, Kerrou K, Pascal O, Cussenot O, Talbot JN: Fluorocholine (18F) and sodium fluoride (18F) PET/CT in the detection of prostate cancer: prospective comparison of diagnostic performance determined by masked reading. Q J Nucl Med Mol Imaging 2011;55:448-457.

59 McCarthy M, Siew T, Campbell A, Lenzo N, Spry N, Vivian J, Morandeau L: (1)(8)F-Fluoromethylcholine (FCH) PET imaging in patients with castration-resistant prostate cancer: prospective comparison with standard imaging. Eur J Nucl Med Mol Imaging 2011;38:14-22.

60 Beheshti M, Imamovic L, Broinger G, Vali R, Waldenberger P, Stoiber F, Nader M, Gruy B, Janetschek G, Langsteger W: 18F choline PET/CT in the preoperative staging of prostate cancer in patients with intermediate or high risk of extracapsular disease: a prospective study of 130 patients. Radiology 2010;254:925-933.

61 Beheshti M, Vali R, Waldenberger P, Fitz F, Nader M, Hammer J, Loidl W, Pirich C, Fogelman I, Langsteger W: The use of F-18 choline PET in the assessment of bone metastases in prostate cancer: correlation with morphological changes on CT. Mol Imaging Biol 2010;12:98-107.

62 Poulsen MH, Bouchelouche K, Gerke O, Petersen H, Svolgaard B, Marcussen N, Svolgaard N, Ogren M, Vach W, Hoilund-Carlsen PF, Geertsen U, Walter S: [18F]-fluorocholine positron-emission/computed tomography for lymph node staging of patients with prostate cancer: preliminary results of a prospective study. BJU Int 2010;106:639-643; discussion 644.

63 Steuber T, Schlomm T, Heinzer H, Zacharias M, Ahyai S, Chun KF, Haese A, Klutmann S, Kollermann J, Sauter G, Mester J, Mikecz P, Fisch M, Huland H, Graefen M, Salomon G: [F(18)]-fluoroethylcholine combined in-line PET-CT scan for detection of lymph-node metastasis in high risk prostate cancer patients prior to radical prostatectomy: Preliminary results from a prospective histology-based study. Eur J Cancer 2010;46:449-455.

64 Husarik DB, Miralbell R, Dubs M, John H, Giger OT, Gelet A, Cservenyak T, Hany TF: Evaluation of [(18)F]choline PET/CT for staging and restaging of prostate cancer. Eur J Nucl Med Mol Imaging 2008;35:253-263.

65 Vees H, Buchegger F, Albrecht S, Khan H, Husarik D, Zaidi H, Soloviev D, Hany TF, Miralbell R: 18F-choline and/or 11C-acetate positron emission tomography: detection of residual or progressive subclinical disease at very low prostate-specific antigen values $(<1 \mathrm{ng} / \mathrm{mL})$ after radical prostatectomy. BJU Int 2007;99:14151420.

66 Hacker A, Jeschke S, Leeb K, Prammer K, Ziegerhofer J, Sega W, Langsteger W, Janetschek G: Detection of pelvic lymph node metastases in patients with clinically localized prostate cancer: comparison of [18F] fluorocholine positron emission tomography-computerized tomography and laparoscopic radioisotope guided sentinel lymph node dissection. J Urol 2006;176:2014-2018; discussion 2018-2019.

67 Kwee SA, Coel MN, Lim J, Ko JP: Prostate cancer localization with 18fluorine fluorocholine positron emission tomography. J Urol 2005;173:252-255.

68 Curigliano G, Pelosi G, De Pas T, Renne G, De Cobelli O, Manzotti M, Spitaleri G, de Braud F: Absence of epidermal growth factor receptor gene mutations in patients with hormone refractory prostate cancer not responding to gefitinib. Prostate 2007;67:603-604.

69 Haseebuddin M, Dehdashti F, Siegel BA, Liu J, Roth EB, Nepple KG, Siegel CL, Fischer KC, Kibel AS, Andriole GL, Miller TR: 11C-acetate PET/CT before radical prostatectomy: nodal staging and treatment failure prediction. J Nucl Med 2013;54:699-706.

70 Mena E, Turkbey B, Mani H, Adler S, Valera VA, Bernardo M, Shah V, Pohida T, McKinney Y, Kwarteng G, Daar D, Lindenberg ML, Eclarinal P, Wade R, Linehan WM, Merino MJ, Pinto PA, Choyke PL, Kurdziel KA: 11C-Acetate PET/CT in localized prostate cancer: a study with MRI and histopathologic correlation. J Nucl Med 2012;53:538-545.

71 Jambor I, Borra R, Kemppainen J, Lepomaki V, Parkkola R, Dean K, Alanen K, Arponen E, Nurmi M, Aronen HJ, Minn H: Functional imaging of localized prostate cancer aggressiveness using 11C-acetate PET/CT and 1H-MR spectroscopy. J Nucl Med 2010;51:1676-1683.

72 Jambor I, Borra R, Kemppainen J, Lepomaki V, Parkkola R, Dean K, Alanen K, Arponen E, Nurmi M, Aronen HJ, Minn H: Improved detection of localized prostate cancer using co-registered MRI and 11C-acetate PET/ CT. Eur J Radiol 2012;81:2966-2972. 


\section{Cellular Physiology Cell Physiol Biochem 2016;39:467-480 \begin{tabular}{l|l} 
DOI: 10.1159/000445639 & $\begin{array}{l}\text { O 2016 The Author(s). Published by S. Karger AG, Basel } \\
\text { www.karger.com/cpb }\end{array}$ \\
\cline { 2 - 3 } &
\end{tabular}}

Liu et al.: PET/CT for PCa diagnosis

73 Wachter S, Tomek S, Kurtaran A, Wachter-Gerstner N, Djavan B, Becherer A, Mitterhauser M, Dobrozemsky G, Li S, Potter R, Dudczak R, Kletter K: 11C-acetate positron emission tomography imaging and image fusion with computed tomography and magnetic resonance imaging in patients with recurrent prostate cancer. J Clin Oncol 2006;24:2513-2519.

74 Yang Z, Hu S, Cheng J, Xu J, Shi W, Zhu B, Zhang Y, Yao Z, Pan H: Prevalence and risk of cancer of incidental uptake in prostate identified by fluorine-18 fluorodeoxyglucose positron emission tomography/computed tomography. Clin Imaging 2014;38:470-474.

75 Damle NA, Bal C, Bandopadhyaya GP, Kumar L, Kumar P, Malhotra A, Lata S: The role of 18F-fluoride PET$\mathrm{CT}$ in the detection of bone metastases in patients with breast, lung and prostate carcinoma: a comparison with FDG PET/CT and 99mTc-MDP bone scan. Jpn J Radiol 2013;31:262-269.

76 Hwang I, Chong A, Jung SI, Hwang EC, Kim SO, Kang TW, Kwon DD, Park K, Ryu SB: Is further evaluation needed for incidental focal uptake in the prostate in 18-fluoro-2-deoxyglucose positron emission tomography-computed tomography images? Ann Nucl Med 2013;27:140-145.

77 Minamimoto R, Uemura H, Sano F, Terao H, Nagashima Y, Yamanaka S, Shizukuishi K, Tateishi U, Kubota Y, Inoue T: The potential of FDG-PET/CT for detecting prostate cancer in patients with an elevated serum PSA level. Ann Nucl Med 2011;25:21-27.

78 Shiiba M, Ishihara K, Kimura G, Kuwako T, Yoshihara H, Sato H, Kondo Y, Tsuchiya S, Kumita S: Evaluation of primary prostate cancer using 11C-methionine-PET/CT and 18F-FDG-PET/CT. Ann Nucl Med 2012;26:138145.

79 Picchio M, Messa C, Landoni C, Gianolli L, Sironi S, Brioschi M, Matarrese M, Matei DV, De Cobelli F, Del Maschio A, Rocco F, Rigatti P, Fazio F: Value of [11C]choline-positron emission tomography for re-staging prostate cancer: a comparison with [18F]fluorodeoxyglucose-positron emission tomography. J Urol 2003;169:1337-1340.

80 Oyama N, Akino H, Kanamaru H, Suzuki Y, Muramoto S, Yonekura Y, Sadato N, Yamamoto K, Okada K: 11C-acetate PET imaging of prostate cancer. J Nucl Med 2002;43:181-186.

81 Fricke E, Machtens S, Hofmann M, van den Hoff J, Bergh S, Brunkhorst T, Meyer GJ, Karstens JH, Knapp WH, Boerner AR: Positron emission tomography with 11C-acetate and 18F-FDG in prostate cancer patients. Eur J Nucl Med Mol Imaging 2003;30:607-611.

82 Price DT, Coleman RE, Liao RP, Robertson CN, Polascik TJ, DeGrado TR: Comparison of [18 F]fluorocholine and $[18 \mathrm{~F}]$ fluorodeoxyglucose for positron emission tomography of androgen dependent and androgen independent prostate cancer. J Urol 2002;168:273-280.

83 Kotzerke J, Volkmer BG, Neumaier B, Gschwend JE, Hautmann RE, Reske SN: Carbon-11 acetate positron emission tomography can detect local recurrence of prostate cancer. Eur J Nucl Med Mol Imaging 2002;29:1380-1384.

84 de Jong IJ, Pruim J, Elsinga PH, Vaalburg W, Mensink HJ: 11C-choline positron emission tomography for the evaluation after treatment of localized prostate cancer. Eur Urol 2003;44:32-38; discussion 38-39.

85 Bauman G, Belhocine T, Kovacs M, Ward A, Beheshti M, Rachinsky I: 18F-fluorocholine for prostate cancer imaging: a systematic review of the literature. Prostate Cancer Prostatic Dis 2012;15:45-55.

86 Effert PJ, Bares R, Handt S, Wolff JM, Bull U, Jakse G: Metabolic imaging of untreated prostate cancer by positron emission tomography with 18fluorine-labeled deoxyglucose. J Urol 1996;155:994-998.

87 Macara IG: Elevated phosphocholine concentration in ras-transformed NIH 3T3 cells arises from increased choline kinase activity, not from phosphatidylcholine breakdown. Mol Cell Biol 1989;9:325-328.

88 DeGrado TR, Reiman RE, Price DT, Wang S, Coleman RE: Pharmacokinetics and radiation dosimetry of 18F-fluorocholine. J Nucl Med 2002;43:92-96.

89 Hara T, Kosaka N, Kishi H: Development of (18)F-fluoroethylcholine for cancer imaging with PET: synthesis, biochemistry, and prostate cancer imaging. J Nucl Med 2002;43:187-199. 